\title{
Social Police Regarding the Transformation of Family
}

\author{
Rezarta Shehu \\ Lecturer, University of Tirana, \\ Faculty of Social Sciences, Department of Sociology \\ E-mail: rezarta.shehu@gmail.com
}

\section{Doi:10.5901/jesr.2013.v3n3p271}

\section{Abstract}

The most important social institution is the family. Each individual, as a member of a society takes the first lessons of his life within the family. So the family is really the first school in the formation of everyone's character. Naturally arises the question whether the family will continue to maintain its functions as reproductive, material and moral? The concept of family has changed from time to time.It is worth it to emphasise that the existence of the family will be apraised, although it constantly evolves. Is there a desire to create something compact where reigns love and care for each other and also everyone's desire to inherit his genes as one of the primary goals of human beings How is freedom understood? How will individuals react to the responsabilities. The new and modern factors (such as technology development, new forms of cohabitation, welfare, individualism and competition even within familles) are negatively or positively affecting the existence or destruction of the family as one of the most important cells of all time.

\section{Methodology and Main Objectives of Studying}

Information used in this study is based on different sources. This study is based on existing albanian and foreign literature.

Its aim is to identify through empirical research, studies and documents everything that has to do with the future of the family as an important cell, for survival or weakening the core values and family.

The interviews mainly contain structured and half-structured questions, with the intention to allow the freedom of expressing thoughts, assessments, comments and suggestions.

It has always been a topic of interest, relations arising in this social institution as well as the influence that society, individual and various social organizations have.

\section{Introduction}

The family has had and will always have its important functions, which although changes are often subjected to historical, political, economic or social, although time has transformed key values back to a family cohabitation, which it seems to have survived. This is the fundamental reason that empowers family.

If we refer to albanian reality may be noted that there were many changes in the conception of the family, taking into account new forms of cohabitation, marriage age has increased, and the number of members of a family has been reduced. Also it is worth mentioning that the position of women in families and in our social reality has changed, the position of women is more favorable, she participates in politics, and business. The relations between spouses have changed also, the relationship between parents and children has changed too. Nowadays it has more freedom in making decisions and in building personal life according to the wishes of everyone.

It is almost everywhere mentioned that moral, economic support and reproduction, have been the most essential functions of the family. It is worth it to mention also the basis of renewed life of any individual referred to social life, some of the existing literature, as well as many articles based on the press, as well as TV shows, who constantly discuss the importance of family emergency.

The most important thing is the fact that, like religion accepts, the family will continue to be the most sacred place for all humanity.

Another question will arise like: How can the family functions maintain the importance of passing the value on new generations?

- Who should play the primary role in educating young people? 
- We also know that the new generations will be the ones who will create the future families.

- What is the role of the school, society and its institutions concerned with social welfare and continuity of the family?

All these questions are intended to reveal not only the role of the family, but also the importance of its continuity as a necessity for society. It seems that the modern world has deeply affected the family, marriage and therefore the individual by society created previously unforeseen problems.

Wife, mother, daughter are an essential starting point in educating children, the education of the future, so it is even more important to analyze its role.

\section{To analyze how it has changed the position of women in Albanian society, starting from:}

- Feminist Movements

- Women's rights

- Establishment of organizations and associations for the protection of women, etc.

- Problems that have accompanied the woman in a patriarchal society like our society.

Such discussions have always been the focus for many media organizations worldwide for women. It is very imperative most likely obligatory women's education, since they make almost half of the world's population. Women often have been victims of stigmas, prejudice and practice has shown that many rights have been denied. Before the 90s, women were almost minor, not being respected, and almost not having human rights.

Nowadays it has changed and they are introduced to their rights and also they were employed or educated. Unemployment among them was massive, probably due to the fact that women are primarily interested in finding a job that provides more prestige than income. When it comes to education, and to make this affirmation in society rather than the desire for economic autonomy or independence from the rest of the family. The experience of developed countries of the world has shown how important it is to get educated an individual, the importance of an educated woman, it can affect, mitigate and overcome conflicts, provides invaluable contribution to the upbringing and education children, also gives its contribution to various organizations on a humanitarian mission. Women have been biased and physically abused, but also psychologically.

Over the years and nowadays, women are gaining more favorable position in society, improving its image and making the voice of the creature, which is considered more fragile. Occupying an important place in society, leadership and decision-making positions, both in parliament, court and other positions.

\section{New forms of coexistence and their impact on family breakdown, and individual freedom.}

Domestic violence, mostly affecting women and girls, causing damage to their dignity and personality. "Experience is vital and socio-psicologic studies prove that such a form of violence in a bad education significantly affects girls and more often causes troubles, which will indicate their personality". (Dervishi, 2000)

Traces of domestic violence expressed in any activities and relationships, in which a female acts, causing them to feel helpless, passive, subdued, failed and powerless to change the course of life, or fate. Violence generates violence, failure also generates failure.

So, a woman psychologically and physically abused by prejudices and opinions, a person who has known only violence, will be keen to convey this to her children. In fact today, individuals seem to be more aware of independence and freedom, the position of women, who are educated, career doing if hired, not even neglected to care for children and the elderly. "Many scholars, prominent theologians, etc, think that increasing the level of education of girls and women, especially mothers will affect directly and indirectly to reducing violent elements in society". (Dervishi, 2000)

Today we have new discussions, coming under the course of time, as a consequence of the economic independence of women, social changes, from technological progress, sexual freedom, new alternatives to the family, leaving the family in this way in the background and not doing the most important functions carried her.

It seems like the only thing that really matters in creating a family and sexuality is precisely when the passion starts off, partners, one or both are in search of new emotions, hence decreasing the values and importance of the family institution. It is not good to make this comparison, but the family is not as creating a new business, which if it goes bankrupt, can open another family and so loses its functions. Divorce is more important than conflict resolution, dialogue, tolerance, mutual contribution from both domestic partners, etc.. It is observed, a kind of stalemate, a kind of pessimism, 
(Tushi, 2012) in terms of young people in the creation of stable, significant and eternal, not the holy family, marriage, relationships of genuine spirituality.

David Poponoe contends that a growing culture of individualism and self-fulfillment, began eroding Swedish families in the 1960. (Poponoe, 1997)

Sweden is one example, that David Poponoe, brings us as a family company which has gone weaker globally. This developing country with a high socio-economic, social problems has softened quite a few things such as crime, drug abuse, poverty, but in terms of family, seems to have turned out as a disappointment. Individuals passively avoid the assistance from the state, not as formerly married, but as a couple who live together and there is also an increase of children outside marriage too. The individual is being transformed into an individualistic, selfish, who care only for their narrow personal interests.

The state has replaced the family, while we have to turn to culture and should continue to support strong ties between family members, spouses parents and children, not down the foundations of the family, as a necessity for the welfare of the individual in particular and society in general. What actually does cause it and what if society runs the risk of weakening the family, as one of the most important social institutions?

"It seems to be the case, however, that cohabitation has both a negative and a positive effect on divorce". (Poponoe, 2009)

The consequences are numerous, ranging from the collapse of attention to the education of children, family conflicts, divorce experienced by children rather than by the spouses. So we will increase crime, increase problems such as smoking, alcoholism, abuse, drugs, sexual freedom and most of all suicides among teenagers. Thus, the weakening of family versus society puts such emergency situations and very harmful, causing chaos. The modern era has replaced marriage with cohabitation, such as the increase of extramarital relationships, where family obligations and responsibilities, are not so important. The desire for sexual freedom and career have become essential. "It is already reduced the role of marriage and family as a consequence of the structure of economic existence. Marriage is a social and awkward relation, unstable and easily changeable. Emerging social phenomenon of finding alternate who compete, overlap and replace marriage". (Tushi, 2012)

\section{Transformation of the family and its essential functions}

Scholars, researchers, sociologists and different journalists assess the situation and propose addictive, once back from the culture, traditions return, return some value to the past. Although it is difficult to come by, it must be admitted that some values of the past have been positive and productive for the living society. Should eliminate negative elements, which lead to regression society, should be replaced with other, adapting time, dynamics and social change inevitable. Also, the proposed educational programs and support for couples, children in schools, to help the family of the woman, not charge it more. For its own social contribution, making it unique as workforce, but also to educate and care for her children and family.

The family is being transformed every day. It is losing its essential functions. Sexuality and extramarital relationships are becoming increasingly important.

Especially young people, are suffering serious doubt and fear to take a significant step as starting a family. To be noted pessimism to create a consolidated family and social foundations of.

Passion, it seems that it's becoming the most important thing, by claiming that the only reason that keeps two people together, as long as there is. But when passion is extinguished, the trend is divorce and divorce statistics in our society are growing so scary.

Human values such as humanity, loyalty, respect for traditional family healthy, losing the rhythm of time. In fact each vertex there is a decline in our country and this situation is at its peak. But it will continue and it will hit is difficult to make predictions. The future increasingly viewed with suspicion. Family, marriage, children do not bring joy to the hearts of individuals bef.

"Despite the changes and controversies that have buffeted the family on recent decades, most people still report being happy as partners and parents. Marriage and family life are likely to remain a foundation of our society for many years to come" David Poponoe". (Poponoe, 1997) 


\section{References}

Dervish, Zyhdi. Women in the Eye of the Storm Challenges and Prospects. 2000. Printing house Dora d'Istria. Tirana. page 48-77\& 127135

Omar, Sonila. Family Law. 2010.printing house Morava.Tirana. page 33, 46-48, 50-67

Dervish, Zyhdi. Women in the Turbulences of Mentalities and Political Reality. 2011. printing house Emal.Tirana

Tushi, Gëzim. Martesa, Familja, Seksualiteti. 2012. printing house Natyre. Tirana. page 14-55

Nicholson, Linda. The Myth of Traditional Family. 1997. Chapter 2, page 27-39

Makkai, Toni. Social Policy and Gender in Eastern Europe. 1989. page 188-205

Poponoe, David.The Weakest Families on Earth? A report from Sweden.1997. Chapter 18, Family. Global Sociology

Poponoe, David. Cohabitation, Marriage, Child and Wellbeing: A Cross-National Perspective. 2009. Social Science and Public. page 429-436. Springer Science Media 